\title{
SIMULASI POLA ARUS LAUT DUA DIMENSI DI PERAIRAN SEKITAR NUSA PENIDA, BALI
}

\author{
2D NUMERICAL MODEL OF OCEAN CURRENT IN NUSA PENIDA, BALI
}

\author{
R. Bambang Adhitya Nugraha ${ }^{1}$, Heron Surbakti ${ }^{2}$, Johan Risandi ${ }^{1}$ dan \\ La ode Nurman Mbay ${ }^{1}$ \\ ${ }^{1}$ Pusat Pengkajian dan Perekayasaan Teknologi Kelautan dan Perikanan - Balitbang KP \\ ${ }^{2}$ Prodi Ilmu Kelautan, Universitas Sriwijaya-Palembang \\ E-mail: kangibenk@gmail.com dan heronsurbakti@gmail.com
}

Diterima tanggal: 28 Desember 2013, diterima setelah perbaikan: 7 Maret 2014, disetujui tanggal: 14 Maret 2014

\begin{abstract}
ABSTRAK
Sirkulasi arus laut dua dimensi di sekitar perairan Nusa Penida, Bali telah disimulasikan dengan menggunakan pemodelan numerik hidrodinamika dengan tujuan untuk mengetahui pola arus di lapisan permukaan sekitar perairan Pulau Nusa Penida, Bali. Model numerik difokuskan pada profil kecepatan horizontal dan pola sirkulasi arus permukaan yang dominan dipengaruhi oleh pola pasang surut di daerah tersebut. Hasil komputasi tersebut divalidasi dengan metode Langrangian dari sebuah coastal drifter yang mengikuti pergerakan arus pada saat pengukuran lapangan. Pola arus laut perairan Nusa Penida sangat dipengaruhi oleh kondisi dasar perairan yang dangkal dan pola pasang surut (semidiurnal). Kecepatan rata-rata arus laut di perairan Nusa Penida berkisar antara 0.1-0.95 m/s sedangkan kecepatan maksimum di beberapa titik mencapai kisaran angka 2-2.5 m/s. Berdasarkan diagram probabilitas kecepatan arus laut selama setahun, terdapat 5 titik pengamatan yang memiliki kecepatan arus di atas $1 \mathrm{~m} / \mathrm{s}$ yang dapat dijadikan patokan dalam pengelolaan dan pemanfataan sumber daya pesisir dan laut di sekitar perairan Nusa Penida.
\end{abstract}

Kata kunci: Nusa Penida, MIKE21, probabilitas kecepatan arus laut

\section{ABSTRACT}

A two-dimensional of ocean currents pattern in Nusa Penida, Bali has been simulated using numerical hydrodynamic model in order to determine the flow pattern in the surface layer of the waters around the island of Nusa Penida, Bali. The model is focused on the horizontal velocity profiles and it pattern at the surface layer that are predominantly influenced by tidal patterns. The computational result was validated by the Langrangian method of a coastal drifter follows the movement of the ocean current at the time of field measurements. The ocean current of Nusa Penida is strongly influenced by its bathymetry and semidiurnal pattern of the tide. The average speed of ocean currents is ranged from $0.1-0.95 \mathrm{~m} / \mathrm{s}$ while the maximum speed can reached $2-2.5 \mathrm{~m} / \mathrm{s}$. Based on the probability curve of ocean current speed in a year, there are five observation points have current speed greater than $1 \mathrm{~m} / \mathrm{s}$ which can be used as a bench mark in the management and utilization of coastal and marine resources in the surrounding of Nusa Penida Island.

Keywords: Nusa Penida, MIKE21, probability of ocean current speed

\section{PENDAHULUAN}

Nusa Penida yang terletak diantara Selat Badung dan Selat Lombok merupakan salah satu kecamatan yang masuk dalam wilayah administrasi Kabupaten Klungkung, Provinsi Bali. Kecamatan ini memiliki luas sekitar 20.300 hektar yang terdiri dari 3 pulau utama yaitu Nusa Penida, Nusa
Ceningan dan Nusa Lembongan, yang semuanya dikelilingi oleh terumbu karang tepi (fringing reef). Hal ini menyebabkan perairan ini lebih dangkal dibandingkan dengan perairan Selat Lombok yang berada di sebelah timurnya.

Penelitian parameter oseanografi khususnya tentang arus laut di perairan sekitar Selat Badung dan Kepulauan Nusa Penida masih sangat terbatas 
dan tidak selengkap pola arus di Selat Lombok yang merupakan jalur utama ARLINDO. Yuningsih et al. (2008) memfokuskan penelitian di sekitar perairan Selat Toyopakeh, Nusa Penida untuk menganalisis pola arus pasang surut dan mengidentifkasi besaran rapat daya yang dapat dihasilkan dari pola arus tersebut. Arus di perairan Toyopakeh sangat dipengaruhi oleh kondisi dasar laut (bathymetry) dan pasang surut perairan tersebut (semidiurnal). Kecepatan arus rata-rata di perairan tersebut mencapai $2.5-3.0 \mathrm{~m} / \mathrm{s}$ dengan durasi 9-18 jam/hari untuk kecepatan diatas 0.5 $\mathrm{m} / \mathrm{s}$.

Tujuan dari tulisan ini adalah untuk memberikan gambaran umum pola arus di lapisan permukaan sekitar perairan Pulau Nusa Penida, Bali. Model dua dimensi pola arus ini diharapkan dapat menjadi masukan tambahan dalam pengelolaan dan pembangunan sumber daya di pesisir dan laut perairan tersebut seperti budidaya rumput laut, pariwisata laut dan penelitian energi baru terbarukan (ocean energy).

\section{BAHAN DAN METODE}

Studi ini terdiri dari analisis kecepatan dan arah arus pada kondisi pasang tertinggi dan surut terendah serta ketinggian muka air rata-rata (mean sea level). Model dua dimensi arus dalam tulisan ini menggunakan perangkat lunak MIKE 21 (DHI, 2012). Persamaan yang digunakan dalam model adalah persamaan momentum dan persamaan kontinuitas dengan perata-rataan kedalaman. Model ini menggunakan pendekatan metode beda hingga (finite difference) untuk menyelesaikan persamaan yang digunakan (Surbakti et al., 2011).

Persamaan kontinuitas:

$$
\frac{\partial \zeta}{\partial t}+\frac{\partial p}{\partial x}+\frac{\partial q}{\partial y}=\frac{\partial d}{\partial t}
$$

Persamaan momentum:

Pada sumbu $\mathrm{x}$

$$
\begin{gathered}
\frac{\partial p}{\partial t}+\frac{\partial}{\partial x}\left(\frac{p^{2}}{h}\right)+\frac{\partial}{\partial y}\left(\frac{p q}{h}\right)+g h \frac{\partial \zeta}{\partial x}+\frac{g p \sqrt{p^{2}+q^{2}}}{c^{2} h^{2}} \\
-\frac{1}{\rho_{w}}\left[\frac { \partial } { \partial y } \left(h \tau_{y y}+\frac{\partial}{\partial x}\left(h \tau_{x y}\right]-\Omega_{q}-f V V_{x}\right.\right. \\
+\frac{h}{\rho_{w}} \frac{\partial}{\partial x}\left(\rho_{a)}=0\right.
\end{gathered}
$$

Pada sumbu y

$$
\begin{gathered}
\frac{\partial p}{\partial t}+\frac{\partial}{\partial x}\left(\frac{p^{2}}{h}\right)+\frac{\partial}{\partial y}\left(\frac{p q}{h}\right)+g h \frac{\partial \zeta}{\partial x}+\frac{g p \sqrt{p^{2}+q^{2}}}{c^{2} h^{2}} \\
-\frac{1}{\rho_{w}}\left[\frac { \partial } { \partial y } \left(h \tau_{y y}+\frac{\partial}{\partial x}\left(h \tau_{x y}\right]-\Omega_{q}-f V V_{x}\right.\right. \\
+\frac{h}{\rho_{w}} \frac{\partial}{\partial x}\left(\rho_{a)}=0\right.
\end{gathered}
$$

dimana:

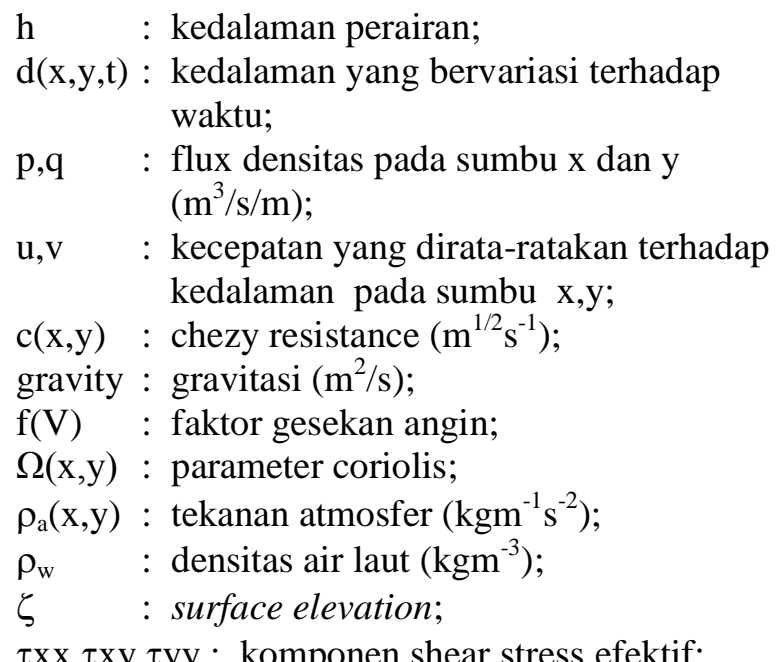

\subsection{Masukan Data}

Data yang digunakan sebagai masukan model adalah sebagai berikut:

\subsubsection{Data Batimetri}

Data batimetri yang digunakan sebagai data masukan pada daerah model (model domain area) adalah hasil digitasi dari peta batimetri lembar peta No: 262 dan 112 dari Dinas Hidro-Oseanografi (DISHIDROS) TNI-AL. Gambar 1 menunjukkan peta batimetri di daerah kajian model.

\subsubsection{Data Angin}

Data angin diperoleh dari ECMWF (The European Centre for Medium-Range Weather Forecasts). Parameter data yang terdapat pada data angin ini adalah data kecepatan angin tiap tiga jam pada periode Januari-Desember 2013 yang terdiri atas komponen timur-barat (zonal) dan komponen utara-selatan (meridional) pada ketinggian $10 \mathrm{~m}$ di atas permukaan laut. 


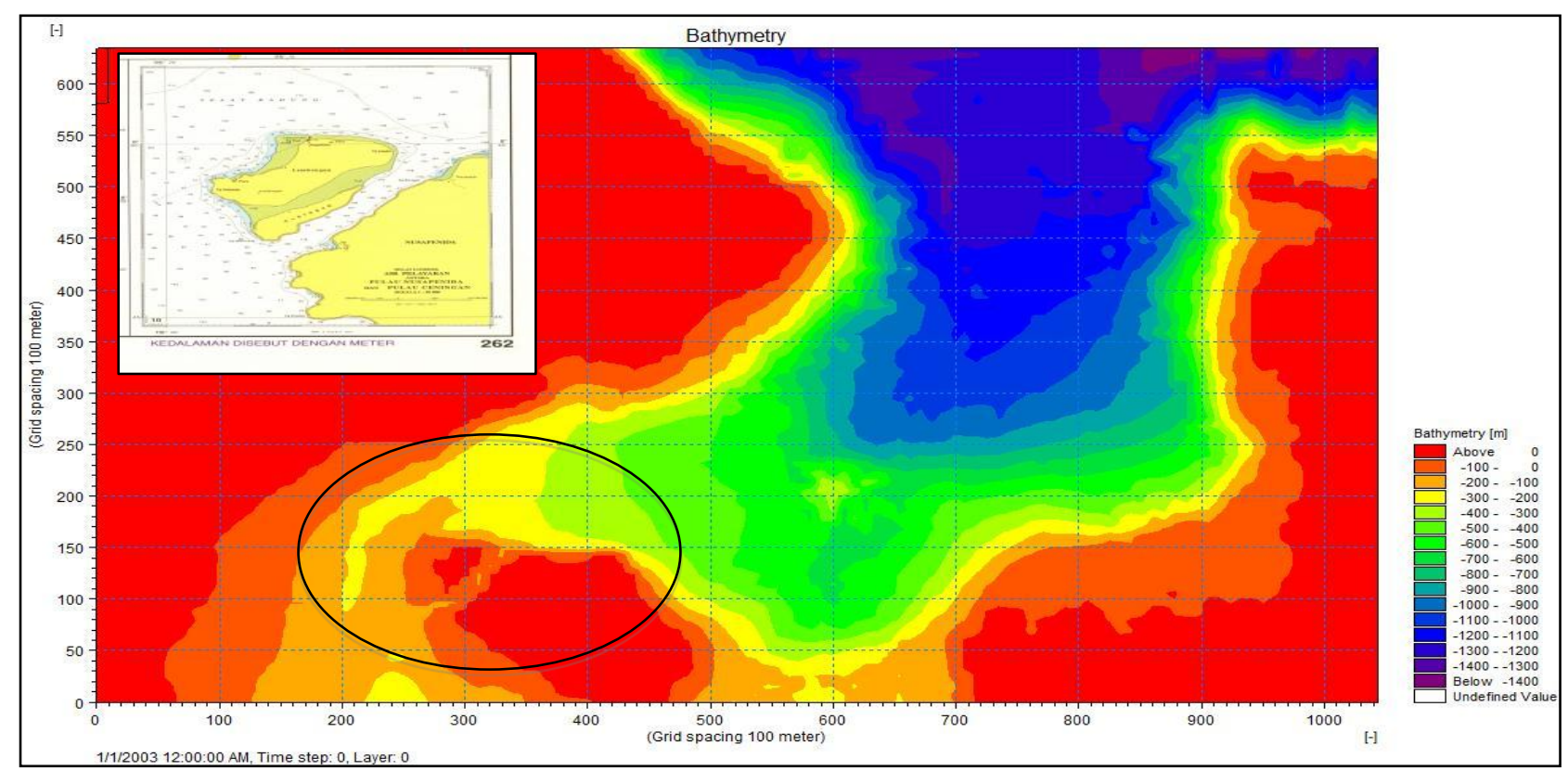

Gambar 1.Batimetri daerah model

Figure 1. Topographic of model area

Sumber: Hasil pengolahan data

\subsubsection{Data Pasang Surut}

Data pasang surut (pasut) yang digunakan sebagai batas terluar model (open boundary condition) merupakan data elevasi pasang surut hasil peramalan DHI Global Tide, yaitu suatu produk pasut global yang dikembangkan oleh DHI Institute dengan resolusi $0.25^{\circ}$, dengan periode yang disesuaikan dengan data angin. Output data pasut DHI Global Tide adalah elevasi muka air dengan kisaran 1 jam. Adapun periode yang digunakan adalah sepanjang tahun 2013. Untuk menyesuaikan dengan langkah waktu yang digunakan dalam model (2 detik) dilakukan interpolasi dengan menggunakan metode spline cubic. Elevasi muka air DHI Global Tide merupakan gabungan dari 8 komponen pasut utama $\left(\mathrm{M}_{2}, \mathrm{~S}_{2}, \mathrm{~K}_{1}, \mathrm{O}_{1}, \mathrm{~N}_{2}, \mathrm{P}_{1}, \mathrm{~K}_{2}, \mathrm{Q}_{1}\right)$.

\subsection{Dikritasi Daerah Model}

Untuk melihat pola hidrodinamika daerah kajian dilakukan dengan nested hydrodynamic model, dimana dibangun model domain besar dan domain kecil.

Untuk model besar dilakukan pembuatan grid berukuran $150 \mathrm{~m}$ x $150 \mathrm{~m}$, sedangkan model kecil dilakukan dengan grid berukuran 50 x $50 \mathrm{~m}$.
Model ini diselesaikan dengan pendekatan numerik metode beda hingga (finite different). Simulasi Numerik dilakukan selama 1 tahun (tahun 2013) dengan langkah waktu setiap 2 (dua) detik. Informasi grid dan parameter data (jumlah grid, dimensi grid dan time step) yang digunakan dalam model hidrodinamika disajikan pada Tabel 1 sedangkan gambaran mengenai domain daerah model ditunjukkan pada Gambar 2.

Tabel 1.Desain model hidrodinamika Table 1. Design of hydrodynamika model

\begin{tabular}{lccc}
\hline \multicolumn{1}{c}{ Parameter } & M.besar & M.kecil & Unit \\
\cline { 2 - 3 } & Value & Value & \\
\hline Jumlah sel x (i) & 232 & 550 & - \\
\hline Jumlah sel y (i) & 150 & 289 & - \\
\hline Ukuran sel $\Delta \mathrm{x}$ dan $\Delta \mathrm{y}$ & 150 & 50 & $\mathrm{M}$ \\
\hline Ukuran sel $\Delta \mathrm{x}$ dan $\Delta \mathrm{y}$ & 150 & 50 & $\mathrm{M}$ \\
\hline Time step of model & & 2 & \\
\hline
\end{tabular}

Sumber: Hasil analisis 


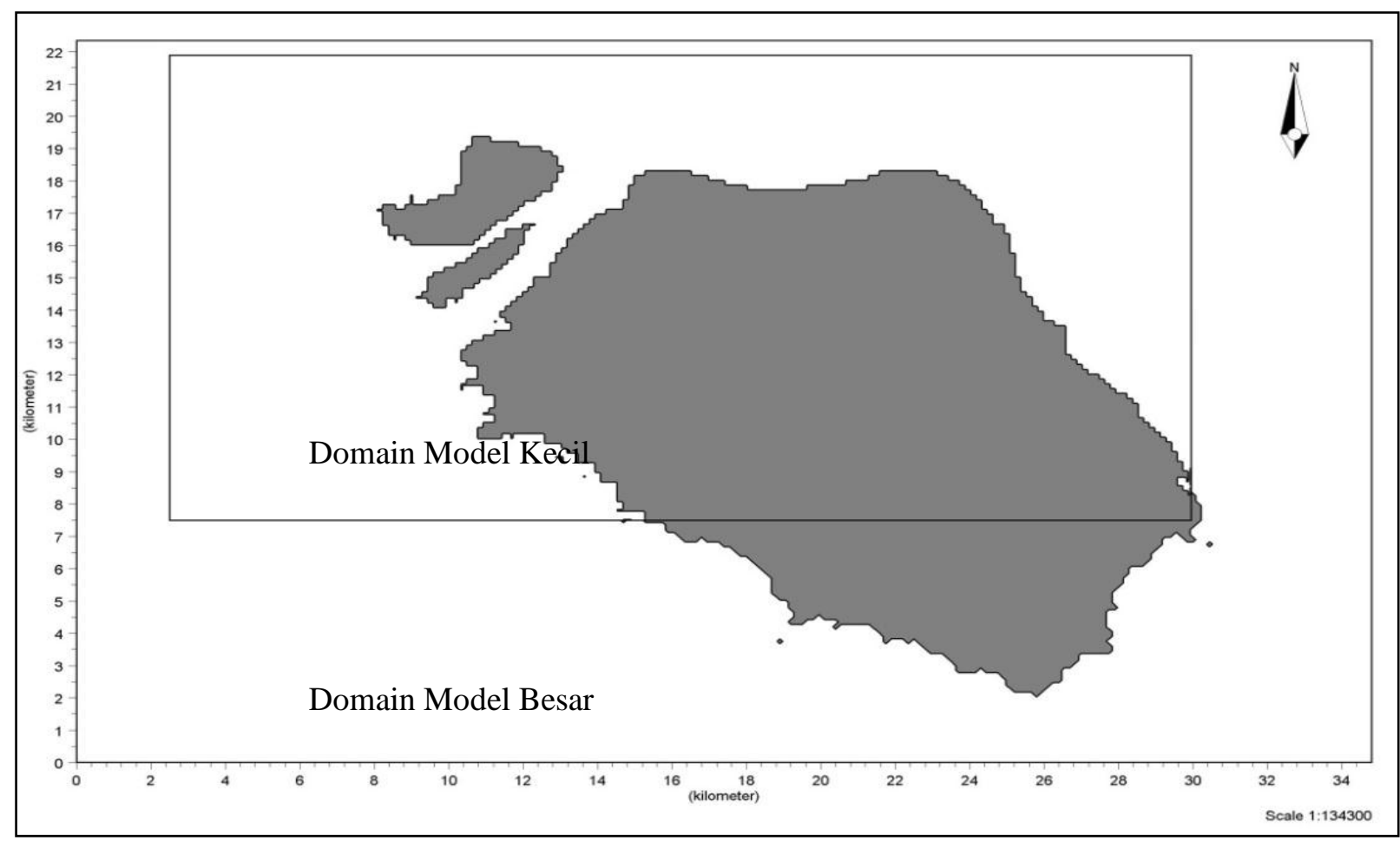

Gambar 2.Grid domain model besar (150 m X $150 \mathrm{~m})$, serta domain model kecil (50 m X $50 \mathrm{~m})$

Figure 2. Domain grid of nested model for different resolution (150m $\times 150 \mathrm{~m}$ and $50 \mathrm{~m} \times 50 \mathrm{~m})$

Sumber: Hasil analisis

Ukuran grid model besar yang digunakan adalah $\Delta \mathrm{x}=\Delta \mathrm{y}=150 \mathrm{~m}$ sedangkan ukuran grid model kecil merupakan sepertiga (1/3) dari ukuran grid mode besar.

\subsection{Pengukuran Lapangan}

Survey lapangan difokuskan pada pengukuran arus laut dengan mempergunakan coastal drifter yang terdiri dari bola buoy, GPS, modem GSM dan mikrokontroller dengan metode Langrangian (Gambar 3).
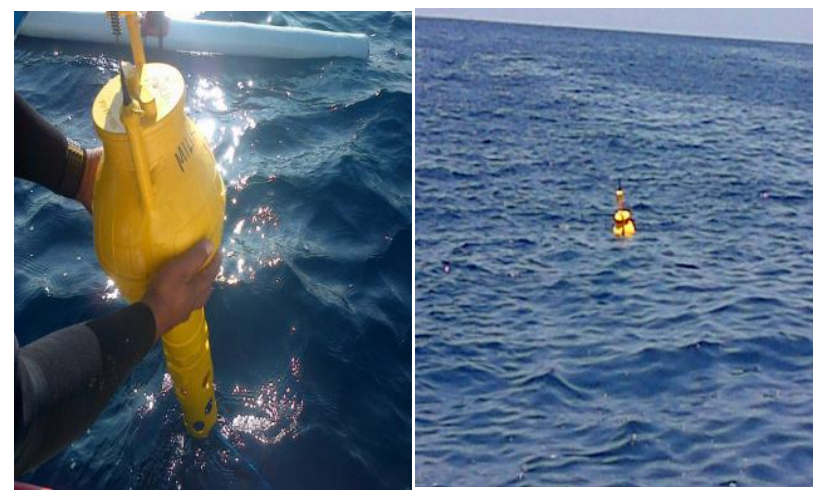

Gambar 3. Coastal drifter yang dipergunakan pada saat survei

Figure 3. The coastal drifter was used at field survey Sumber : Abundo, et. At, 2010; Hu, et.al 1995; Lumpkin and Pazos, 2007; Qiu, 2011; Iqbal, 2011
Pengukuran lapangan dilaksanakan tanggal 2-3 Oktober 2013. Coastal drifter yang digunakan memiliki ketelitian $4.5 \mathrm{~m}$. Penentuan posisi memerlukan selang waktu tertentu, selang waktu ini sangat bergantung dari kecepatan arus permukaan di daerah tersebut. Semakin cepat semakin kecil selang waktu yang bisa diimplementasikan

\section{HASIL DAN PEMBAHASAN}

\subsection{Verifikasi Model}

Verifikasi model arus telah dilakukan untuk mengetahui apakah model yang dibangun sesuai atau tidak dengan kondisi di lapangan. Hasil verifikasi antara data yang dihasilkan dari simulasi numerik dan pengukuran lapangan ditampilkan pada Gambar 4. Gambar 4 menunjukkan lintasan trajectory/garis jejak dari buoy yang mengikuti pergerakan arus sebenarnya yang diplotkan bersamaan dengan data arus hasil model. Lintasan trajectory arus hasil pengukuran (warna hijau) dan hasil simulasi (warna hitam) menunjukkan pola yang sama. Hal ini menunjukkan bahwa hasil simulasi telah mendekati/merepresentasikan kondisi yang sebenarnya di lapangan. Berdasarkan 
hasil simulasi (pada lokasi dan periode yang sama dengan pengukuran), kecepatan arus laut akibat pengaruh pasang surut di sekitar perairan Nusa Penida berkisar antara $0.1-2.5 \mathrm{~m} / \mathrm{s}$ dengan arah dominan menuju ke barat-barat daya dari P. Nusa Penida dan P. Nusa Lembongan. Arus laut tersebut memiliki nilai kecepatan dan arah yang sama dengan yang terekam oleh coastal drifter yaitu berkisar antara 0.37-2.43 m/s dengan arah dominan yang sama, barat-barat daya.
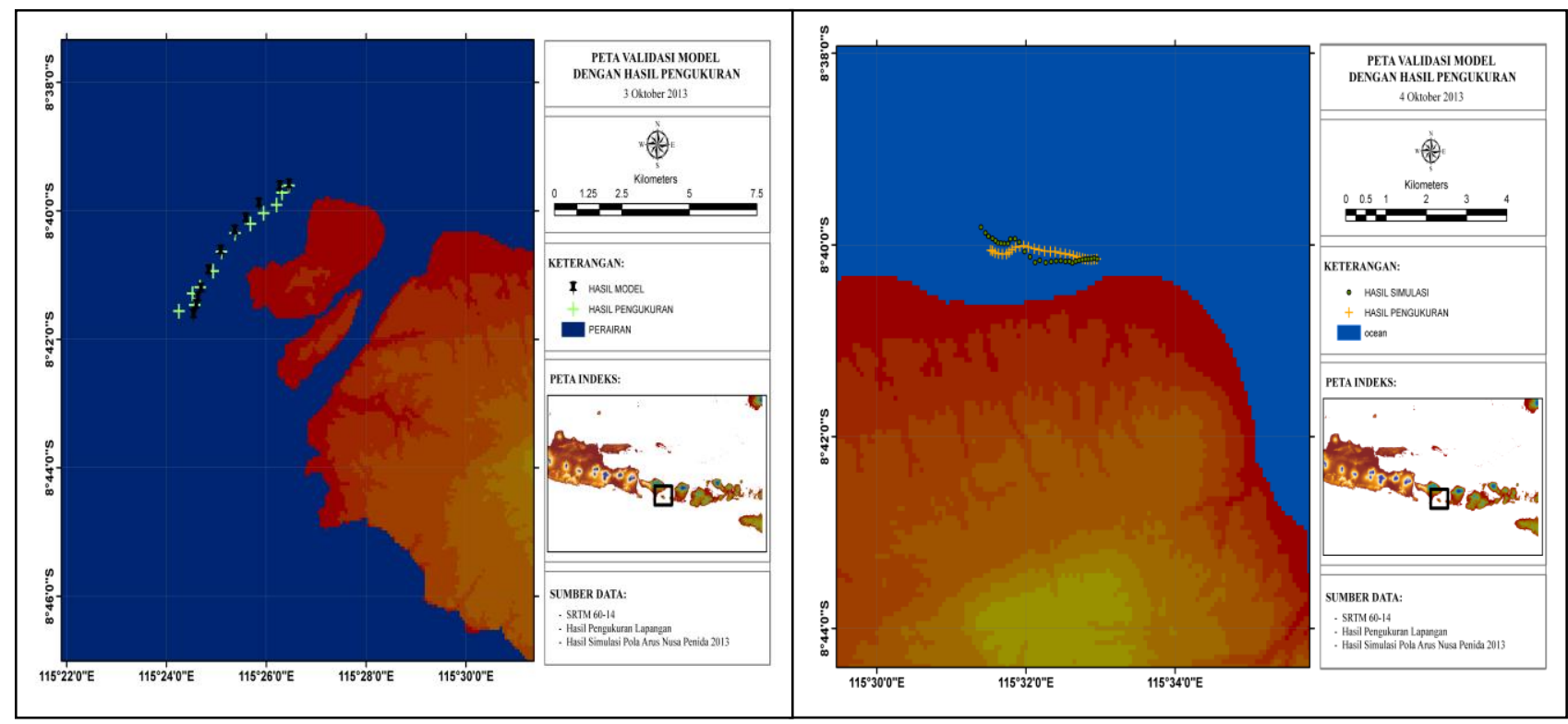

Gambar 4.Perbandingan data antara model numeric dan coastal drifter pada waktu yang sama di bagian barat P. Nusa Lembongan dan utara P. Nusa Penida

Figure 4. Comparison of data derived from numerical models and coastal drifter at the same time in the west of Nusa Lembongan Island and north of Nusa Penida Island Sumber: Hasil pengolahan data

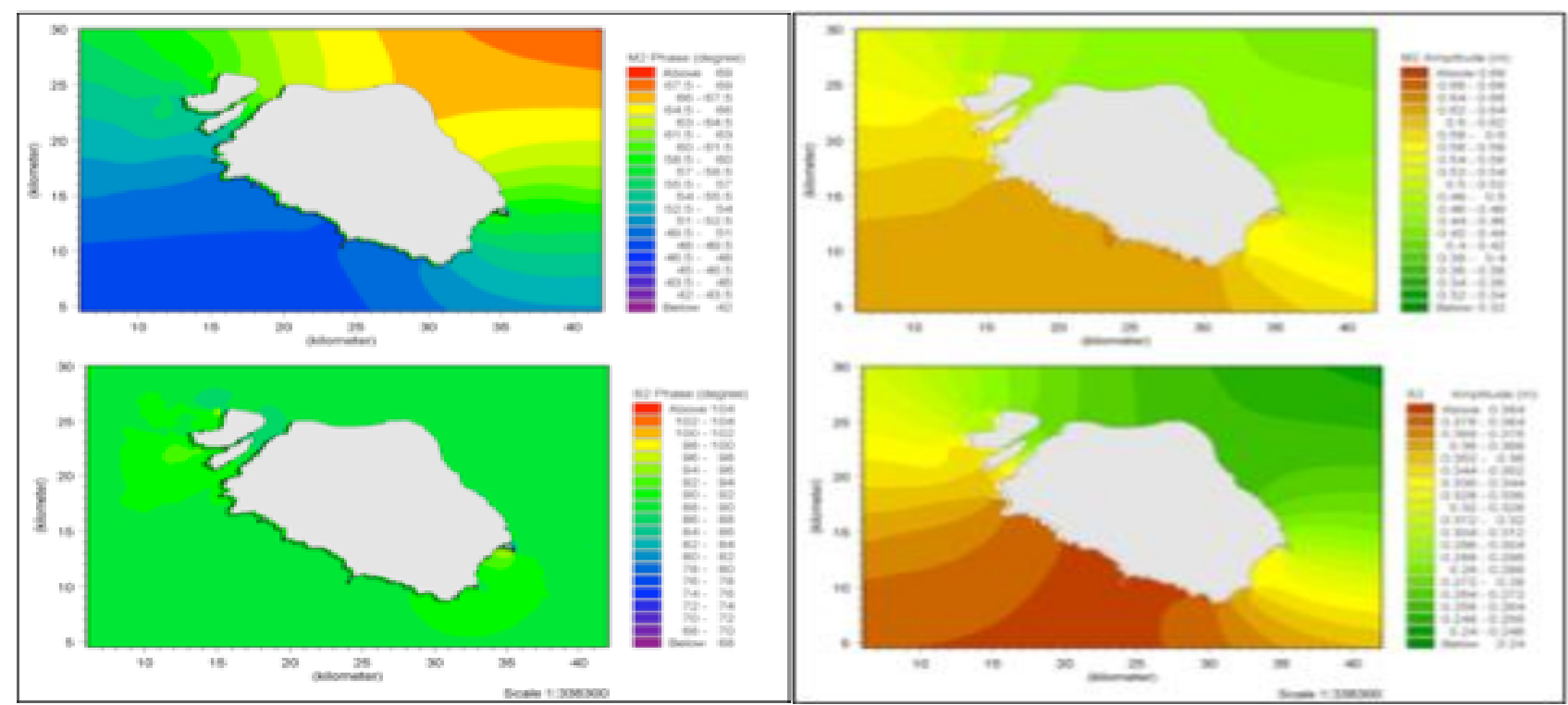

Gambar 5. Amplitudo dan beda fasa untuk komponen pasut ganda utama (M2 dan S2)

Figure 5. Amplitude and phase for semidiurnal component (M2 and S2)

Sumber: Hasil pengolahan data 
Hal ini ditunjukkan dengan nilai konstanta pasut dimana nilai amplitude dan beda fasa komponen pasut ganda utama (M2 dan S2) lebih besar dibandingkan dengan komponen pasut tunggal utama (Gambar 5) di atas. Nilai amplitude dan beda fase komponen pasut ganda utama (M2 dan S2) berturut-turut berkisar antara 0.24-0.68 $\mathrm{m}$ dan $42-104^{0}$ sedangkan nilai amplitude dan beda fasa komponen pasut tunggal utama (O1 dan K1) berturut-turut berkisar antara 0.15-0.27 $\mathrm{m}$ dan 146$172^{0}$.

Gambar 6 dan 7 berturut-turut menunjukkan pola arus laut di titik MSL (Mean Sea Level) menuju pasang tertinggi dan titik MSL menuju surut terendah dan pada surut terendah di sekitar Pulau Nusa Penida pada periode bulan Oktober 2013.
Nilai kecepatan setiap kondisi tersebut ditabulasikan pada Tabel 2.

Saat kondisi menuju pasang tertinggi, arus memasuki perairan Selat Badung dan sekitarnya bergerak ke selatan keluar menuju Selat Lombok dan/atau Samudera Hindia dengan dengan kecepatan maksimum mencapai $1.5 \mathrm{~m} / \mathrm{s}$ dan ratarata $0.40 \mathrm{~m} / \mathrm{s}$. Sedangkan pada saat menuju surut terendah, arus secara umum bergerak berlawan arah dari kondisi pasang tertinggi yaitu bergerak masuk menuju perairan Selat Badung dan sekitar Nusa Penida serta keluar ke arah utara menuju Selat Lombok dan/atau Laut Flores dengan kecepatan maksimum dan rata-rata yang lebih besar dari kondisi pasang tertingginya yaitu 1.60 $\mathrm{m} / \mathrm{s}$ dan $0.64 \mathrm{~m} / \mathrm{s}$.

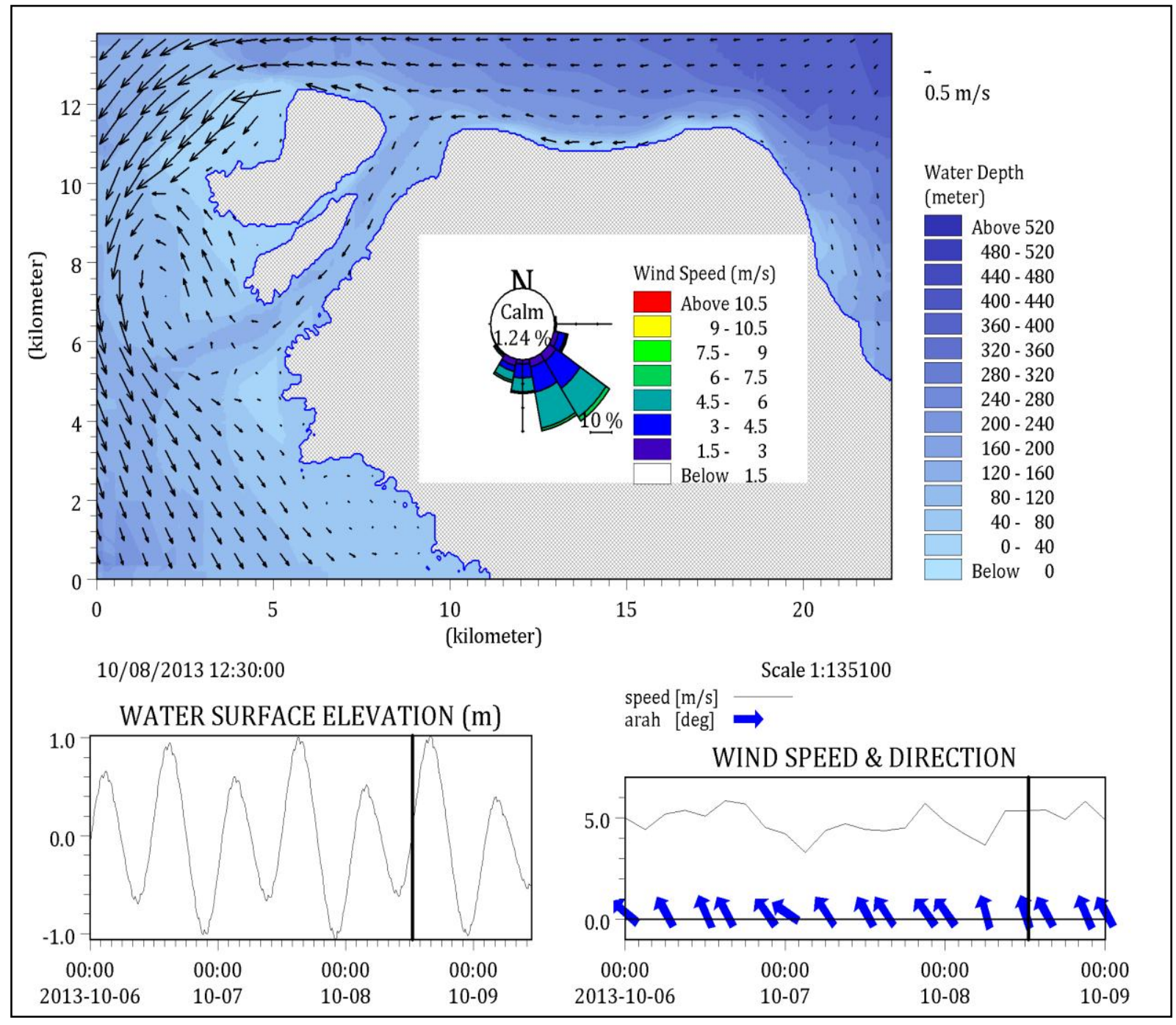

Gambar 6. Pola arus hasil simulasi pada saat menuju pasang tertinggi

Figure 6. The numerical simulation of ocean current during the flood tide Sumber: Hasil analisis 


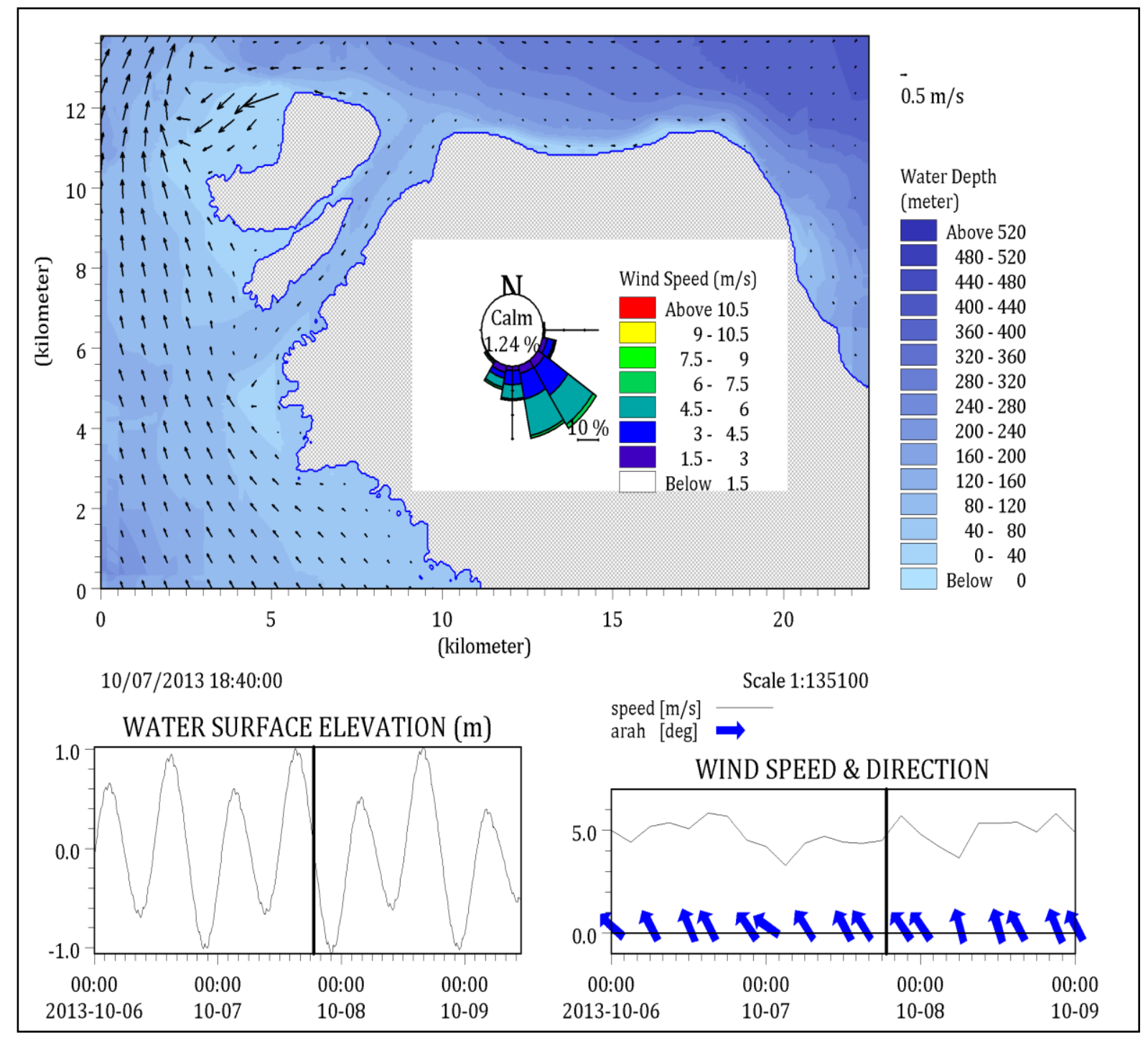

Gambar 7. Pola arus hasil simulasi pada saat menuju surut terendah

Figure 7. The numerical simulation of ocean current during the ebb tide Sumber: Hasil analisis

Tabel 2. Kecepatan arus hasil simulasi pada empat posisi muka laut berbeda di sekitar perairan Nusa Penida

Table 2. Speed of current simulation result's on fours different face position in current Nusa penida

\begin{tabular}{lcc}
\hline \multicolumn{1}{c}{ Kondisi Muka Air } & $\begin{array}{c}\text { Kec. Maks } \\
(\mathbf{m} / \mathbf{s})\end{array}$ & $\begin{array}{c}\text { Kec. Rataan } \\
(\mathbf{m} / \mathbf{s})\end{array}$ \\
\hline $\begin{array}{l}\text { MSL Menuju Surut } \\
\text { Terendah }\end{array}$ & 1.60 & 0.64 \\
\hline Surut Terendah & 1.05 & 0.23 \\
\hline $\begin{array}{l}\text { MSL menuju Pasang } \\
\text { Tertinggi }\end{array}$ & 1.50 & 0.40 \\
\hline Pasang Tertinggi & 1.41 & 0.49 \\
\hline Sumber: Hasil analisis & &
\end{tabular}

Terlihat bahwa dari area model yang dibangun, terdapat 5 titik/area yang memiliki kecepatan arus (rata-rata dan maksimum) yang sepanjang tahun dominan dibandingkan dengan area lainnya. Lokasi-lokasi tersebut adalah:

- Titik 1: Barat daya Pulau Nusa Lembongan;

- Titik 2: Barat laut Pulau NusaLembongan

- Titik 3: Barat Pulau Nusa penida

- Titik 4: Barat daya Pulau Nusa Penida

- Titik 5: Utara Pulau Nusa Penida

Kecepatan rata-rata arus laut di perairan Nusa Penida berkisar antara 0.1-0.95 m/s sedangkan kecepatan maksimum di beberapa titik mencapai kisaran angka 2-2.5 m/s. Hal ini sesuai dengan penelitian pola arus yang dilakukan oleh P3GL di sekitar perairan Selat Toyopakeh, Nusa Penida, Bali, yang menyatakan bahwa kecepatan arus laut 
di perairan Nusa Penida berkisar antara 0.5- 3.28 $\mathrm{m} / \mathrm{s}$. Kecepatan arus maksimum pada saat Neap Tide $2.46 \mathrm{~m} / \mathrm{s}$ dan saat Spring Tide $3.29 \mathrm{~m} / \mathrm{s}$. Perbedaan nilai maksimum tersebut kemungkinan disebabkan oleh perbedaan lapisan perairan pada saat pengukuran kecepatan arus laut dan model simulasi maupun validasi model arus laut di lapangan yang dilakukan. Nilai kecepatan $3.29 \mathrm{~m} / \mathrm{s}$ yang dihasilkan PPGL diukur pada kedalaman diatas $10 \mathrm{~m}$ sedangkan simulasi kecepatan arus maupun pengukuran lapangan pada kegiatan ini dilakukan kurang lebih pada kecepatan $<5 \mathrm{~m}$.

Berdasarkan analisis hasil model pada 5 titik observasi, probabilitas arus di sekitar perairan Nusa Penida mencapai kecepatan $3.29 \mathrm{~m} / \mathrm{s}$ sangat kecil seperti yang digambarkan pada Gambar 9 yang menunjukkan diagram probabilitas (prosentase kejadian) dari setiap nilai kecepatan arus yang dihasilkan dari model numerik. Pada 5 titik observasi, prosentase kejadian nilai kecepatan arus $>1 \mathrm{~m} / \mathrm{s}$ mencapai lebih dari 50\%. Pada titik 2 sedangkan pada titik 3 kejadian kecepatan arus $>1$ $\mathrm{m} / \mathrm{s}$ sangat kecil seperti ditampilkan pada Tabel 3 .

Pada titik 2 dan titik 5 terjadi kecepatan arus diatas $2 \mathrm{~m} / \mathrm{s}$ dengan prosentase kejadian masing-masing sebesar $34.14 \%(2,991 \mathrm{jam})$ dan $3.82 \%$ (335 jam). Nilai kecepatan $>2 \mathrm{~m} / \mathrm{s}$ tersebut menjadi sangat penting untuk dimanfaatkan sebagai masukan dalam pembuatan desain dan pembangunan konstruksi/struktur PLTAL sehingga turbin arus laut tersebut dapat bertahan dalam kondisi ekstrem pada saat kondisi kecepatan arus laut maksimum.

Tabel 3. Prosentase kejadian nilai kecepatan arus $>1$ $\mathrm{m} / \mathrm{s}$

Table 3. Presentation of fenomena with value's speed $>$

\begin{tabular}{|c|c|c|}
\hline \multicolumn{3}{|c|}{$1 \mathrm{~m} / \mathrm{s}$} \\
\hline \multirow[t]{2}{*}{ Titik 1} & Jumlah Jam & 2,763 \\
\hline & $\%$ & 31.54 \\
\hline \multirow[t]{2}{*}{ Titik 2} & Jumlah Jam & 5,205 \\
\hline & $\%$ & 59.41 \\
\hline \multirow[t]{2}{*}{ Titik 3} & Jumlah Jam & 434 \\
\hline & $\%$ & 4.95 \\
\hline \multirow[t]{2}{*}{ Titik 4} & Jumlah Jam & 1,139 \\
\hline & $\%$ & 13.00 \\
\hline \multirow[t]{2}{*}{ Titik 5} & Jumlah Jam & 2,054 \\
\hline & $\%$ & 23.44 \\
\hline
\end{tabular}

Sumber: Hasil pengolahan data

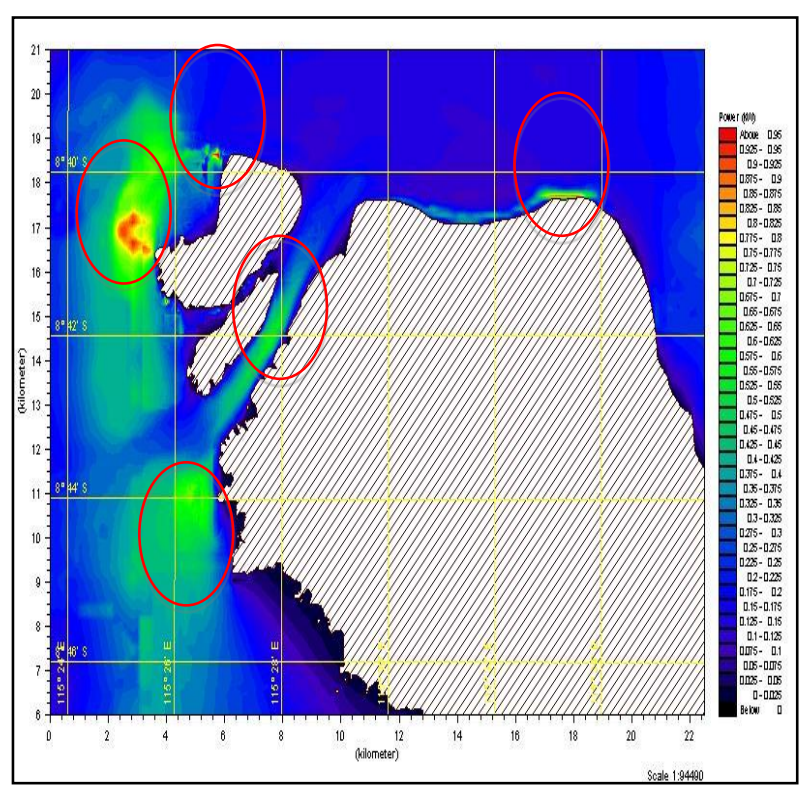

Gambar 8. Arus rata-rata setahun di sekitar perairan Nusa Penida, Bali

Figure 8. Mean velocity of ocean current in surrounding of Nusa Penida, Bali Sumber: Hasil pengolahan data

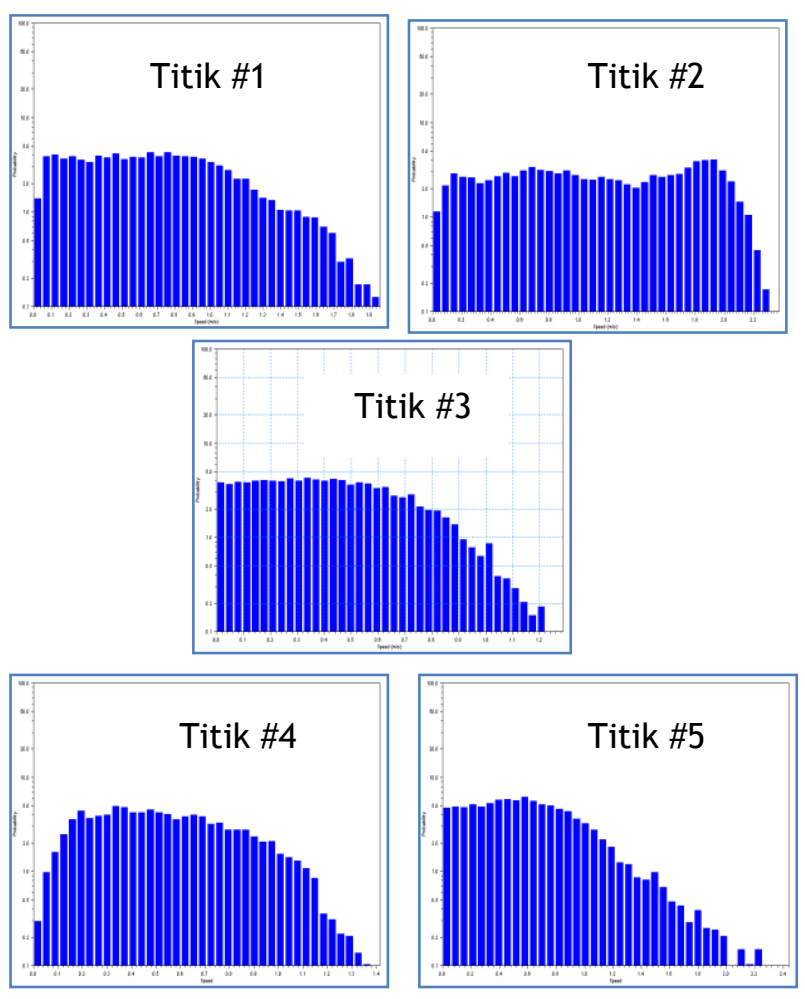

Gambar 9. Diagram probabilitas kecepatan arus laut di titik 1-5

Figure 9. Diagram of ocean current speed probability at study area

Sumber: Hasil pengolahan data 


\section{KESIMPULAN DAN SARAN}

Hasil model simulasi arus mempunyai nilai arah dan kecepatan yang sama dengan hasil pengukuran dengan menggunakan coastal drifter dengan metode trajectory.

Berdasarkan simulasi model, kecepatan rata-rata arus laut di perairan Nusa Penida berkisar antara 0.1-0.95 $\mathrm{m} / \mathrm{s}$ dengan kecepatan maksimum di beberapa titik mencapai kisaran angka $2-2.5 \mathrm{~m} / \mathrm{s}$. Diketahui pula bahwa berdasarkan diagram probabilitas kecepatan arus dan analisis prosentase kejadian terdapat 5 titik observasi di sekitar perairan Nusa Penida dan atau Selat Badung yang sepanjang tahun memiliki kecepatan di atas $1 \mathrm{~m} / \mathrm{s}$. Hal ini sangat berguna untuk pengelolaan dan pemanfaatan di wilayah pesisir dan laut sekitar Nusa Penida.

\section{DAFTAR PUSTAKA}

Abundo, M.L.S., Belbes, J.L., Cruz, X.A., Liong, V.E., Talampas, M.C., David, L. \& Villanoy, C. (2010). Drifters as preliminary site assessment tool for ocean current-based renewable energy for straits and channels in the Philippines. IPEC, 2010 Conference Proceedings, pp. 413, 417, 2729 Oct 2010. doi: 10.1109/ IPECON.2010.5697168

Arief, D., \& Murray, S. P. (1996). Low-frequency fluctuations in the Indonesian throughflow through Lombok Strait. J. Geophys. Res., 101(C5), 12.455-12.464.

Hasannudin, M. (1998). Arus lintas Indonesia (Arlindo). Oseana. Vol XXIII, Nomor 2. ISSN 0216 1877. Hal. 1-9.

Hu, J. W., You, I. H., Lee, C. Y., Huang, C. H. O. (1995). The development and application of GPS drifter for ocean current measurement. In
Proceeding of Current Measurement, 1995., Proceeding of The IEEE Fifth Working Conference. Dept. of Oceanografi., Nat. Taiwan Ocean University, Keelung 03/1995; DOI: 10.1109/CCM.1995.516169. ISBN: 0-78032437-4.

Iqbal, M., Jaya, I dan Purba, M. (2011). Rancang bangun dan uji kinerja drifter buoy. Jurnal Teknologi Perikanan dan Kelautan, 1(2), 57-70.

Lumpkin, R., \& Pazos, M. (2007). Measuring surface currents with surface velocity program drifters: the instrument, its data, and some recent results. In Lagrangian Analysis and Prediction of Coastal and Ocean Dynamics, Chapter: 2. Cambridge University Press.

Mukhtasor., Waskitoaji, W., Pandoe, W. W., Iswadi, A., Firdaus, A.M dan Aliyanti, K. (2013). Rancangan Peta Jalan Regulasi Energi Laut: Draft Version. ASELI dan Deputi Jaringan IPTEK - Kementerian Riset dan Teknologi.

Murray, Y. S., \& Arief, D. (1988). Through flow into the Indian Ocean through the Lombok Strait. January 1986. Nature, 313, 444-447.

Qiu, Y., Li L, Chen, C-T. A., Guo, X., \& Jing C. (2011). Currents in the Taiwan Strait as observed by surface drifters. Journal of Oceanography, 67(4), 395-404.

Surbakti, H., Purba, M. \& Nurjaya, IW. (2011). Pemodelan pola arus di perairan pesisir Banyuasin, Sumatera Selatan. Maspari Journal, 3(1), 9-14.

Susanto, R. D., \& Gordon, A. L. (2005). Velocity and transport of the Makassar Strait throughflow. J. Geophys. Res., 110, C01005. doi:10.1029/ 2004JC002425.1-11

Yuningsih, A., Masduki, A., Rachmat, B., \& Prijantono, A. (2008). Penelitian Potensi Energi Arus Laut Sebagai Pembangkit Listrik Bagi Masyarakat Pesisir di Selat Badung, Nusa Penida, Bali. Puslitbang Geologi Kelautan Bandung. Tidak dipublikasikan. 